\title{
Aikuisten osallistuminen koulutukseen 2012
}

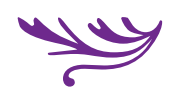

\begin{abstract}
Uusimman aikuiskoulutustutkimuksen (AKU2012) mukaan yli 1,7 miljoonaa suomalaista aikuista osallistuu vuosittain koulutukseen. Miehistä osallistuu 45 ja naisista 58 prosenttia. Edelliseen, vuoden 2006 tutkimukseen verrattuna osallistuminen on pysynyt täsmälleen samalla tasolla. Sen sijaan koulutukseen käytettyjen päivien määrä on selvästi vähentynyt jo yli kymmenen vuoden ajan.
\end{abstract}

TILASTOKESKUS ON TOTEUTTANUT yhteistyössä opetus- ja kulttuuriministeriön kanssa koko väestön kattavaa tutkimusta aikuiskoulutukseen osallistumisesta vuodesta 1980. Vuodesta 1990 lähtien tutkimus on toistettu noin viiden vuoden välein. Vuosien 2006 ja 2012 aikuiskoulutustutkimukset ovat osa Euroopan unionin aikuiskoulutustutkimusta, jota koordinoi EU:n tilastovirasto Eurostat. Noin 30 maassa 2011-2012 toteutettu tutkimus (Adult Education Survey, EU-AES) mahdollistaa laajan kansainvälisen vertailun. Seuraava tiedonkeruu on suunniteltu vuodelle 2016.

Uusimman aikuiskoulutustutkimuksen perusjoukkona ovat Suomessa pysyvästi asuvat 18-69-vuotiaat. Kyseessä on otantatutkimus. Vuonna 2012 otos oli 6149 henkilöä. Aineistonkeruun ensisijainen menetelmä oli tietokoneavusteinen käyntihaastattelu. Kadon pienentämiseksi tutkimukseen otettiin toiseksi tiedonkeruumenetelmäksi puhelinhaastattelu, jota käytettiin tilanteissa, joissa haastateltava ei suostunut käyntihaastatteluun. Vastausosuus oli 68 prosenttia. (Tilastokeskus 2013.)

AKU2012-tutkimuksessa aikuiskoulutuksella tarkoitetaan "aikuisille järjestettyjä ohjattuja oppimistilaisuuksia”. Aikuiskoulutus on rajattu koulutusta antavan organisaation eli oppilaitoksen, koulutusyrityksen tai vastaavan koulutuksen järjestäjän perusteella. Koulutuksen on oltava kestoltaan vähintään kuusi oppituntia. Aikuiskoulutukseen osallistumista selvitetään tutkimuksessa haastattelua edeltävien 12 kuukauden viiteajanjaksolta. Näin saadaan eri maista vertailukelpoista tietoa koulutukseen osallistumisesta yhden vuoden aikana. Vertailutietoja osallistumisen yleisyydestä eri maissa ei ole vielä julkistettu.

Tutkimussarjaa edelsi Heikki Lehtosen ja Jukka Tuomiston vuonna 1972 tekemä postikysely ai- 
kuiskoulutukseen osallistumisesta (ks. Lehtonen \& Tuomisto 1974). Tuolloin kohdejoukkona olivat 16-64-vuotiaat ja otoksena 1 440, joka oli tuohon aikaan melkoinen. Sitä voidaan pitää suomalaisen aikuiskoulutuksen osallistumistutkimuksen pioneerina. Takavuosina Opetushallituksen ylitarkastaja Jukka Katajisto (1984a; 1984b; 1991) tapasi päivittää tietojamme aikuiskoulutuksen osallistumismuutoksista kirjoittamalla Aikuiskasvatus-lehteen. Erja Moore (2004) puolestaan on analysoinut lehden sivuilla osallistumisen esteitä ja osallistumattomuuden problematiikkaa. Toistaiseksi kerätyillä aineistoilla saadaan aikuiskoulutukseen osallistumisesta piirrettyä jo lähes 40 vuoden aikasarja.

\section{OSALLISTUMINEN 1970-LUVULTA 2010-LUVULLE}

Aikuisväestön osallistuminen koulutukseen on kasvanut 1970-luvun alusta nykypäiviin noin 20 prosentista yli 50 prosenttiin (kuvio 1). Lukumäärinä muutos tarkoittaa koulutukseen osallistuvien lisääntymistä noin 0,7 miljoonasta yli 1,7 miljoonaan. Vuonna 1972 kerätyn aineiston mukaan sukupuolten välinen ero oli mitättömän pieni. Vuonna 1980 ero oli kymmenen prosenttiyksikköä naisten hyväksi. Kahdessa uusimmassa mittauksessa (2006 ja 2012) ero on aiempia vuosia suurempi, 13 prosenttia.

Kaikkein suurin kasvu osallistumisessa ajoittuu 1980-luvulle, jolloin aikuiskoulutus nostettiin koulutuspolitiikassa aivan uudenlaiseen asemaan. Se alettiin nähdä paitsi keinona sopeutua teknologiseen muutokseen, myös talouden rakennemuutoksia edesauttavana välineenä. Tämä koulutuspoliittinen painotus kuvastuu myös siinä, että aikuiskoulutus "ammatillistui" nopeasti. Lehtosen ja Tuomiston (1974) mukaan kolmannes aikuiskoulutukseen osallistuneista osallistui ammatilliseen ja loput kaksi kolmasosaa yleissivistäviin ja harrastusopintoihin vuonna 1972. Nyt aikuiset osallistuvat koulutukseen nimenomaan työelämän tarpeista.

Osallistumisosuuksien kasvu taittui 2000-luvun alkuvuosina. Vuonna 2000 naisista osallistui aikuiskoulutukseen 59 ja miehistä 49 prosenttia. Sen jälkeen ero hieman kasvoi, ja naisten osuudet ovat pysytelleet 58 prosentissa ja miesten 45:ssä. On arveltu, että aikuis-
Kuvio 1. Aikuiskoulutukseen osallistuminen (\%) Suomessa sukupuolen mukaan vuosina 1972, 1980, 1990, 1995, 2000, 2006 ja 2012. (Vuosi 1972: osuus 16-64-vuotiaasta väestöstä; muut vuodet: osuus 18-64-vuotiaasta väestöstä; lähteet: Lehtonen \& Tuomisto 1974; Tilastokeskus).

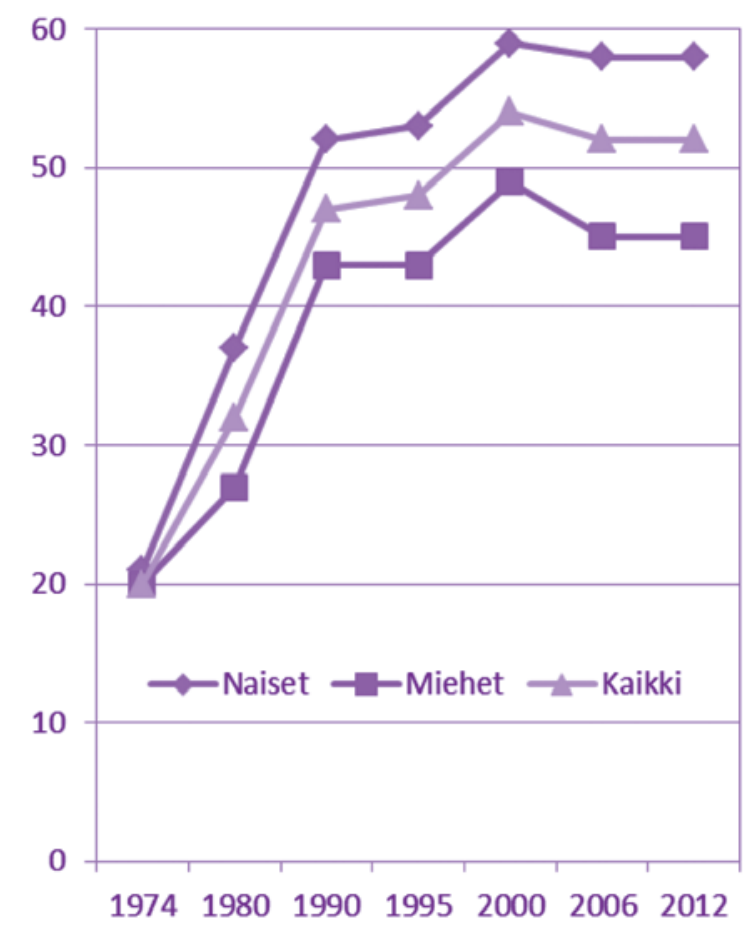

koulutukseen osallistuminen on saavuttanut jonkinlaisen saturaatiopisteen, jonka jälkeen osallistumista ei enää saada lisääntymään vanhoilla keinoilla. Tähän näyttävät viittaavan myös uusimmat tulokset. Kyse ei kuitenkaan ole mistään yleisestä lainalaisuudesta, vaan syyt niin osallistumisen kasvuun kuin pysähtymiseen voivat olla esimerkiksi maakohtaisia.

Vuoden 2012 tulokset kertovat pienoisesta yllätyksestä: aikuiskoulutuspäivien lukumäärä on vähentynyt suorastaan jyrkästi vuoden 2000 tasosta. Miesten koulutuspäivien määrä on vähentynyt 10,2 päivästä 7,2 päivään ja naisten 15,1 päivästä 10,7 päivään. Vuosien 2006 ja 2012 välisenä aikana koulutuspäivien määrä on vähentynyt erityisesti naisilla. Iän mukaisessa tarkastelussa paljastuu toinen mielenkiintoinen muutos: koulutuspäivät ovat vähentyneet etenkin nuorimmissa ikäryhmissä. Sen sijaan 35-44-vuotiaiden, 45-54-vuotiaiden ja 55-64-vuotiaiden ryhmissä määrä on vuoden 2000 tasolla.

Iso osa koulutuspäivien vähenemisestä on seurausta työnantajan kustantaman koulutuksen supistu- 
misesta. Ylempien toimihenkilöiden henkilöstökoulutuspäivien määrä on vähentynyt 9,6 päivästä 7,1 päivään ja alempien toimihenkilöiden 6,8 päivästä 5,5 päivään (kuvio 2). Varsinkin työntekijöiden henkilöstökoulutuksen määrä suorastaan romahti koulutuspäivien lähes puolittuessa 4,1 päivästä 2,5 päivään vuodesta 2006 vuoteen 2012. Koulutuspäivien määrät ovat supistuneet lähes vuoden 1990 lukemiin. Koulutuksen kasautuminen on tutkimuksesta tuttu ilmiö, mutta se ei vähennä sosiaalisten erojen seuraamisen tärkeyttä aikuiskoulutustutkimuksessa, kuten Ari Antikainen osallistumistutkimusta tässä lehdessä (Aikuiskasvatus 2/2011) jokin aika sitten kommentoi.

\section{SIVISTYS- JA HARRASTUSOPINTOIHIN OSALLISTUMINEN}

Vielä 1970-luvulla aikuiskasvatus ja aikuiskoulutus miellettiin harrastusopintoina ja osallistumisena vapaan sivistystyön piirissä tarjottuun koulutukseen. Kansanopisto, kansalais- ja työväenopistot ja esimerkiksi iltakoulut olivat kaikki yleissivistäviä opintomuotoja erotuksena esimerkiksi 1960-luvun lopulta lähtien lisääntyneisiin aikuisten ammattikursseihin. Vuonna 2012 aikuisväestöstä noin kuudesosa eli 520000 henkilöä osallistui yleissivistävään tai harrastustavoitteiseen (eli "muuhun kuin työhön ja ammattiin liittyvään”) aikuiskoulutukseen. Käytännössä yleissivistävässä tai harrastustavoitteisessa koulutuksessa on kysymys juuri vapaan sivistystyön opintoihin osallistumisesta.

Väestön keskimääräinen osallistumisosuus on pysynyt hämmästyttävän tasaisena (18 prosentissa) kahdenkymmenen vuoden ajan (kuvio 3). Sukupuolittaista vaihtelua on jonkin verran. Pienoista muutosta on ollut vuosien 2000 ja 2006 mittauksissa, mutta vuosien 1990, 1995 ja 2012 osallistumisosuudet ovat täsmälleen yhtä suuret miehillä ja naisilla. Sukupuolten erot tekevät vapaasta sivistystyöstä naisten koulutusmuodon: osallistujista 70 prosenttia on naisia.

Osallistuminen vapaan sivistystyön opintoihin noudattaa työelämän koulutuksen tapaan kasautumisen mallia: se lisääntyy hankitun pohjakoulutuksen korkeuden myötä. Kaupungissa ja taajamissa asuvat osallistuvat ahkerammin kuin maaseudulla asuvat.

\section{TYÖELÄMÄN AIKUISKOULUTUKSEN EROT}

Työnantajan kustantama koulutus on erittäin merkittävä osa aikuiskoulutusta, kun noin puolet työvoimaan kuuluvista osallistuu siihen vuosittain. Siksi ei ole yhdentekevää, miten työelämässä tarjottavat koulutuspäivät jakautuvat henkilöstöryhmien, ikäryhmien ja sukupuolten kesken. Työelämän koulutus on ollut yhä vahvemmin esillä myös työmarkkinaneuvotteluissa, eikä se kiinnosta vain korkeasti koulutettuja ammattiryhmiä. Julkisen aikuiskoulutuspolitiikan yksi tärkein tavoite on tasa-arvon edistäminen koulutuksessa ja koulutuksen avulla. Näin ollen julkinen koulutuspolitiikka joutuu kaiken aikaa kompensoimaan yksityisen koulutuspolitiikan aiheuttamaa koulutuksellista epätasa-arvoisuutta ja koulutuksen kasautumista jo muutoin paljon koulutusta hankkineille. Siksi on järkevää yrittää vaikuttaa valtiovallan toimin työnantajan kustantaman koulutuksen jakautumiseen eri henkilöstöryhmien kesken. Osallistumiseroja ei pidä päästää vapaasti kasvamaan.

Lokakuussa 2011 työmarkkinaosapuolten tekemään raamisopimukseen jäänyt kiista kolmesta koulutuspäivästä sai ratkaisunsa vasta lähes kahden vuoden kuluttua, kun työmarkkinoiden keskusjärjestöt elokuussa 2013 allekirjoittivat neuvottelutuloksen osaamisen kehittämisen toimintamallista. Kiistanalaiseksi jäänyt kolmen päivän koulutusoikeus korvattiin "osaamisen kehittämisen toimintamallilla”. Mallissa tulevat tärkeään asemaan työpaikoilla tehtävät koulutussuunnitelmat, joissa on oltava yrityksen kanta ammatillisen osaamisen kehittämisestä kattaen kaikki henkilöstöryhmät tarkoituksenmukaisesti jaoteltuna. Suunnitelmaan on sisällytettävä henkilöstön koulutuksen ja kehittämisen aikataulutus ja seuranta. Työnantajia kannustetaan kouluttamaan henkilöstöään koulutussuunnitelman mukaisesti verovähennysten avulla. Verotuksessa voi vähentää puolet työntekijöiden keskimääräisestä päiväpalkasta sivukuluineen kerrottuna koulutuspäivien lukumäärällä. Vähennyksen enimmäismäärä on kolme päivää työntekijää kohden vuodessa.

Lisäksi verolainsäädäntöä on määrä muuttaa niin, ettei työntekijä joudu maksamaan veroa työnantajan kustantamasta koulutuksesta, kun se tähtää työntekijän ammattitaidon ylläpitämiseen tai kehittämiseen 
nykyisissä tai tulevissa tehtävissä saman yritysryhmän palveluksessa. Myös tutkintoon johtavaa koulutus voi olla "verovapaata”. Sopimukseen kuuluu, että työntekijän jäädessä pidemmäksi aikaa vaille koulutusta asiasta tulee pyytää selvitys työnantajalta, jonka on selvitettävä, kuinka se jatkossa ylläpitää henkilöiden ammatillista osaamista. Työmarkkinoiden keskusjärjestöistä Akava ei hyväksynyt sopimusta. Sen edustajat uskoivat, että koulutukseen osallistumisesta aiheutuu työntekijöille veromätkyjä, koska sitä ehkäisevää vaatimusta ei kirjattu lakiin. Akavan edunvalvojat myös arvelivat, että työnantaja ryhtyy painottamaan koulutustoiminnassaan pienipalkkaisia.

On erittäin kiintoisaa seurata, miten eri henkilöstöryhmien osallistuminen työnantajan kustantamaan koulutukseen kehittyy lähivuosina. Tasoittuvatko osallistumiserot vai joutuvatko palkansaajat maksamaan veroa työnantajaltaan saamasta koulutusedusta?

Heikki Silvennoinen

kasvatustieteen professori

Turun yliopisto

\section{LÄHTEET}

Antikainen, A. (2011.) Kommentti osallistumistutkimuksesta. Aikuiskasvatus 31(2), 142-143.

Lehtonen, H. \& Tuomisto, J. (1974). Aikuiskoulutus Suomessa: käsitykset ja käyttö.

Yhteiskuntatieteiden tutkimuslaitos. Tutkimuksia A:45. Tampere: Tampereen yliopisto.

Katajisto, J.1984a. Osallistumismuutokset Suomen aikuiskasvatuksessa 1972-1980. Aikuiskasvatus 4(2).

Katajisto, J.1984b. Aikuisopintoihin osallistumisen kasautuminen ja esteet Aikuiskasvatus 4(3).

Katajisto, J.1991. Aikuiskoulutukseen osallistuminen kasautuu entistä enemmän hyväosaisille kehityspiirteitä kahden vuosikymmenen ajalta. Muutokset Suomen aikuiskasvatuksessa 1972-1980. Aikuiskasvatus 11(4), 229-238.

Moore, E. (2004.) Aikuiskoulutukseen osallistumattomuus on myös rationaalista. Aikuiskasvatus 24(3), 206-213.

Tilastokeskus (2013.) Aikuiskoulutustutkimus 2012 ennakkotiedot. Helsinki: Tilastokeskus.
Kuvio 2. Aikuiskoulutukseen käytettyjen päivien määrä henkeä kohti Suomessa sukupuolen mukaan vuosina 1990, 1995, 2000, 2006 ja 2012 (lähde:

Tilastokeskus).

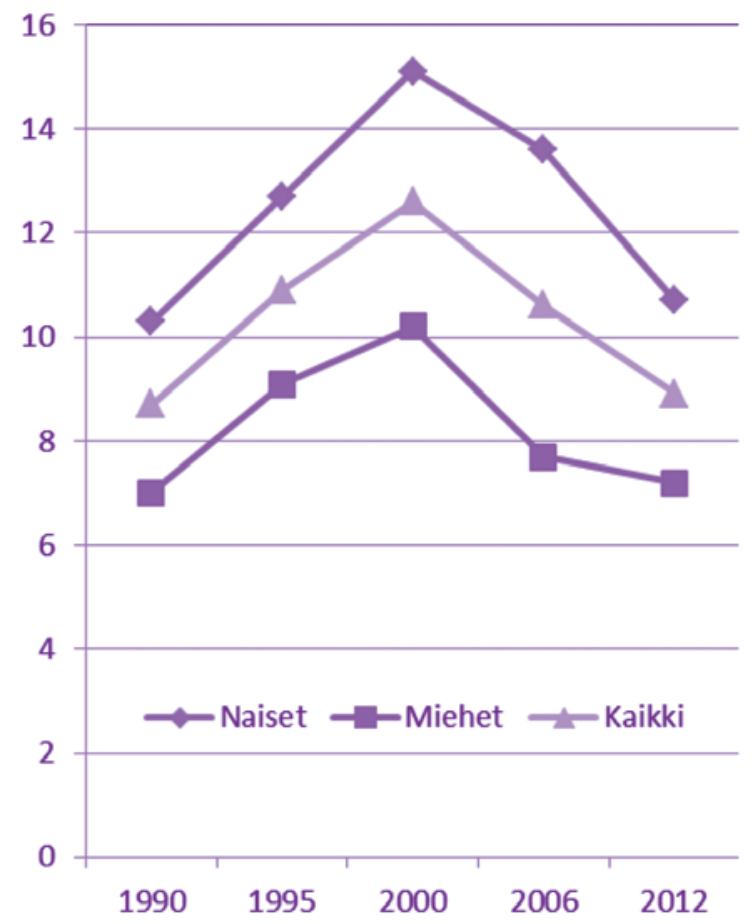

Kuvio 3. Muuhun kuin työhön tai ammattiin liittyvään aikuiskoulutukseen osallistuminen Suomessa sukupuolen mukaan vuosina 1980 , 1990, 1995, 2000, 2006 ja 2012 (\% 18-64-vuotiaasta väestöstä; lähde: Tilastokeskus).

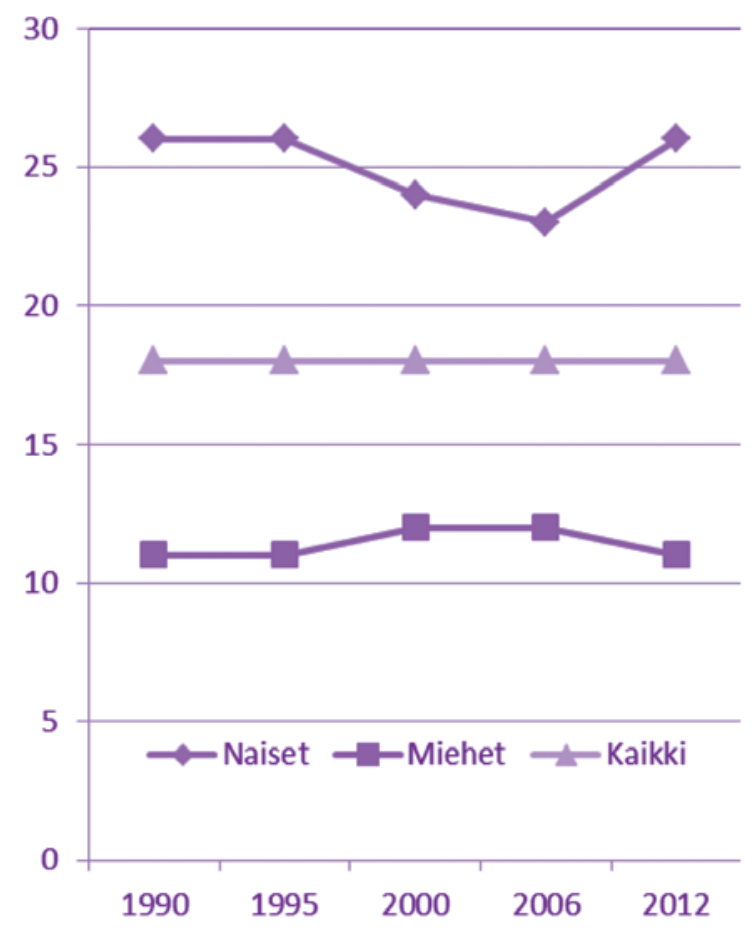

